\title{
Will Religion Survive? A Critical Discussion of the Divergent Answers of two Atheists: Archaeologist David Lewis-Williams and Philosopher of Religion J.L. Schellenberg
}

\author{
Martin Prozesky \\ marproz@mweb.co.za
}

\begin{abstract}
Underlying this article are the questions of how to demarcate the phenomena to which the term 'religion' refers, and of how to differentiate between interpreting and explaining such phenomena - a matter to which David Chidester has offered guidance. These questions are approached by considering a different but closely related question: Does religion have a future, as answered in important recent books by two eminent scholars, both of them atheists, working in very different academic disciplines. These are the books of archaeologist, David Lewis-Williams, Conceiving God: The cognitive origins and evolution of religion (Lewis-Williams 2010) and philosopher of religion, J.E. Schellenberg's more recent work, Evolutionary religion (Schellenberg 2013). These works provide divergent answers to whether religion has a future - a divergence arising from different views about what constitutes religion. This article refers to their respective views, then provides a critical discussion of both, and ends by engaging, where relevant, with ideas in the work of David Chidester.
\end{abstract}

Keywords: future religion, evolution, brain science, unethical religion, explanation, interpretation 


\section{Introduction}

Two recent works by leading scholars offer conflicting accounts about the future of religion. Eminent South African archaeologist, David LewisWilliams, internationally known for his expertise on the meaning of prehistoric rock and cave art, contends in his 2010 book, The cognitive origin and evolution of religion, that religion has no future. Canadian philosopher of religion, J.L. Schellenberg, author of an acclaimed trilogy in his field (Schellenberg 2005; 2007; 2009), offers a very different view in his most recent book, Evolutionary religion (Schellenberg 2013).

Both scholars take science and especially evolution as a given, but they interpret its implications for religion differently; both reveal exceptional knowledge of religion, but also define it differently in reaching their divergent verdicts about what lies ahead for religion. This article presents and contrasts the essentials of their respective accounts. It does so briefly in connection with Lewis-Williams, because much of his important book is a wealth of illustrative and supportive details which need not be mentioned for the purposes of this article; it does so in much greater detail in connection with the views of his Canadian counterpart because of his greater attention to the future of religion. The article then offers a critical conclusion about which account is more persuasive on factual and logical grounds.

\section{Lewis-Williams on the nature and fate of religion}

The book of Lewis-Williams reveals a great erudition about important aspects of religion, brain science, evolution, anthropology, and palaeontology, in which he contends that religion, which he defines as a belief in supernatural beings and forces is a delusion (Lewis-Williams 2010:86) and that religious experience 'is generated by the human nervous system' (Lewis-Williams 2010:232). The preposition 'by' in this quotation is crucial, for he is not saying what many scientifically informed believers like Ashbrook and Albright (1997) would say, that religious experience is generated 'through' the human nervous system. That would leave them logically free to aver that there is at least one supernatural being or force that activates a religious experience by using the nervous system, as very skillfully laid bare by Lewis-Williams. What he means is entirely naturalistic, namely that religious experience arises from 
nothing but the human nervous system and especially from the way the brain works. He therefore argues that there is "no supernatural realm apart from the one that people create inside their heads' (Lewis-Williams 2010:161). According to him, the problem for believers is that such experiences cannot be replicated and verified by others, unlike the way our experience of the natural environment can be checked by others for confirmation or refutation (LewisWilliams 2010:148f).

Lewis-Williams has a very sharp eye for moral and intellectual shortcomings in religion, especially in Christianity, although his criticism occasionally verges on caricature, e.g. his dismissal of Eastern religions as 'consciousness fiddling' (Lewis-Williams 2010:182); his contention about Augustine and Aquinas in the context of notions about demonology and witches, that their 'obsessed, twisted minds verged on madness' (LewisWilliams 2010:181); when he rejects as denialists those, like theologian Alister McGrath, who do not agree that religion is a spent force (Lewis-Williams 2010:259); and when he avers that spirituality is really no more than religion's poor cousin (Lewis-Williams 2010:275).

While such statements are unfortunate, they are few in number and do not detract from the validity of the issues he identifies. While he accepts that there is much good in religion, he is even more aware of evils like the appalling violence of the kind he cites in Mayan religion and the terrible Christian cruelty, earlier in its history, towards those it deemed heretical (LewisWilliams 2010:18-22, 185ff).

For him there is no question of compatibility between religion, understood as belief in supernatural beings and forces, and science, least of all between religion and evolution. He therefore states: 'Rational knowledge has consistently defeated revealed knowledge' (Lewis-Williams 2010:86). He also does not accept the proposal that religion and science represent separate domains, each autonomous in its own domain, because 'religion repeatedly impinges on the domain of science' (Lewis-Williams 2010:117) in ways that cannot be verified, such as religious claims about physical miracles. For him no reconciliation is possible between religion, as he sees it, and science.

Fundamental to his conviction that religion is destined to be eclipsed, being allegedly wanting in its core beliefs, is Lewis-Williams's highly erudite and informative account of how well-known and important religious beliefs, like transcendence and immanence, and the belief in a three-decker universe (clearly expressed and regularly recited in Christianity's Nicene Creed, for 


\section{Martin Prozesky}

example), connect with brain processes. According to him, when people had experiences of hearing voices in the past, or had dreams in which people appeared, these were understandably, but mistakenly, taken to show that there exists what can be called a supernatural realm, inhabited by such beings. Now we know better, he argues.

His handling of this issue is very sophisticated and detailed, especially in the section on Making sense of consciousness (Lewis-Williams 2010:158160). This is, however, not the concern of this article. In the Preface of his book he states that 'religion is the outcome of complex interactions between human neurology, social contexts and repeated practices' (Lewis-Williams 2010:9). Later he adds that we "now know that all our inner experiences have a neurological foundation, even if we are still in the dark about the details of those foundations' (Lewis-Williams 2010:140; cf. also 148, 232ff; emphasis added). The conclusion that Lewis-Williams infers from neurobiology is that people have powerful experiences of supernatural beings and realms because of the way the human brain functions, not because there are such supernatural beings and realms. Since there is no valid, independent evidence of them, he holds that we can rationally conclude that they simply do not exist. Science, therefore, defeats religion by showing its defining feature to be no more than the product of the mind.

Belief in a supposed realm of spiritual beings is, according to LewisWilliams, the defining feature of religion. It is clear that this excludes belief systems like Buddhism, Taoism, and Confucianism, which are otherwise widely included in the movements generally seen as religious. They are excluded because for they make no use of that belief system, even though it is acknowledged in those cultures. Lewis-Williams' view of religion, like that of the philosopher, Grayling (2013), is therefore narrower than that of most leading scholars who have been influential in the field of religion over the past few decades, like Ninian Smart and Richard Hecht (1982), John Hick (1989), and John Hutchinson (1981).

Lewis-Williams has written an impressive book with an immense amount of material about a remarkable range of relevant fields. It should therefore be read by everybody concerned with or about religion. In addition, his criticism of moral and intellectual issues in religion must be squarely faced by believers. He agrees with the view of so-called new atheists like Richard Dawkins (2006) and Sam Harris (2006), that religion is a belief in spiritual beings, and who regards it as a spent force which no well-informed, rational, 
and independently ethical person can accept. The question prompted here is whether he is correct. An important new voice in philosophy of religion argues that they are not.

\section{Schellenberg on the nature and fate of religion}

The aim of Schellenberg's book, Evolutionary religion, is getting people 'to think more seriously about the idea of evolutionary religion' (Schellenberg 2013:6). He rejects the notion held by Lewis-Williams, by some evolutionary scientists, and also by many conservative believers, that evolution and religion are mutually hostile (Schellenberg 2013:2), defining religion quite differently and much more broadly than Lewis-Williams, and also as spanning a far longer period of time. He asserts that

religion throughout our history has seen itself as putting us in touch with higher realities than those of mundane life or the sciences that have proved so clever at charting its regularities. These allegedly higher realities are regarded as capable of benefiting us in distinctive ways, and precisely because they are viewed as higher and greater than mundane realities, the benefits flowing from them are typically regarded as higher and greater than mundane benefits, too (Schellenberg 2013:57).

According to him, religion not only has a future, but evolution allows us to think that it could well have an immensely long future in which it can be expected to evolve into new forms. His suggestion about what such a future faith might be is the most religiously important and interesting part of the book and is discussed below. He argues that, if religion would still undergo a long, evolving future, then the belief that any given religion, like certain monotheisms, is in its final form, is mistaken. This perspective allows Schellenberg to contend that homo sapiens is at present an immature species with an immature spirituality and intellect, and that it can perhaps be expected to evolve much greater brain power in the future, with much greater powers of understanding than anything we now have. 
In his Prologue and first two chapters Schellenberg bases his view that religion is still in a very early stage of development, on the concept of deep time, involving the immensely long past and a future also involving huge spans of time (Schellenberg 2013:8-33). Adopted from science, this perspective about time is based on the scientific consensus that our planet was formed about 4.3 billion years ago; that life appeared around 3.5 billion years ago; that homo sapiens emerged about 200,000 years ago; and that the earliest signs of religious awareness occurred around 50,000 years ago (Schellenberg 2013:3ff).

Monotheistic religions, along with Buddhism, classical Hinduism, and the Chinese religions, have histories of at most a few thousand years. By contrast, the scientific evidence is that life on earth could exist and evolve for another billion years, a calculation based on the astronomical evidence that the sun is slowly getting hotter and will by that time have made the earth too hot for life to survive on it. It follows from this perspective that religion is now at a very early, even infant, stage of its evolution. Keeping well within this immense period of future time, Schellenberg reckons that our species could plausibly exist for another 600,000 years (Schellenberg 2013:4).

Why does Schellenberg think that religion will survive as our species evolves greater brain power, contradicting Lewis-Williams and others? The reason lies in his understanding of the nature of evolution and evolutionary religion. Given the immense period of time that lies ahead for our planet, it is reasonable to expect that life will continue to evolve new forms - that includes homo sapiens. As the human's brain is much larger than those of earlier and related species, it is reasonable to hold that it could become even larger in the future, with greater powers of understanding. Such an evolutionary development would obviously be advantageous to our species, and evolution shows that advantageous changes in a species tend to spread and supersede what has been changed.

In chapters 3 and 4 of his book, Schellenberg (2013:34-70) continues to prepare the ground for his view of religion's future, set forth in the remaining chapters, which form the key part of the book. There he accepts that skepticism like that of Lewis-Williams about present forms of religion is justified, suggesting that religion has perhaps had a bad start, locking us into its present forms and preventing us from moving forward (Schellenberg 2013:90). Against the outright dismissals of religion, Schellenberg contends that such skepticism does not imply the end of religion, holding instead that 'a brand 
new way of being religious emerges... a religiousness that not only tolerates but thrives on skepticism' (Schellenberg 2013:72).

Welcoming everything that modern thought and knowledge reveal, such a new religiousness will have four main features, according to Schellenberg. It will be diachronic rather than synchronic, being sensitive to the vast amount of time that lies ahead; it will be cognitively modest rather than dogmatic; it will be forward-looking and patient; and it will be attentive to what he calls redesigned religion that 'might help us evolve towards ever greater maturity in all areas of human life' (Schellenberg 2013:75).

Turning to the object of a future religiousness, Schellenberg adopts a minimalist view which he calls a 'thin' view because it avoids details, as distinct from 'thick' views that do give details like declaring that the Divine is a family of deities who dwell on Mount Olympus (Schellenberg 2013:93f). In providing his 'thin' view on the object of faith - a view that reveals an accurate understanding of existing religion - Schellenberg contends that some notion of transcendence, also referred to as the Divine, is at the heart of religion, meaning something more than, or deeper and greater than, the world of physical nature explored by science.

$\mathrm{He}$ adds that there are three dimensions of transcendence ("triple transcendence'): First, whatever is held to surpass us, does so in fact ('metaphysical transcendence'); second, in value ('axiological transcendence'); and third, in importance for us ('soteriological transcendence') (Schellenberg 2013:94). He elaborates on these statements, distinguishing between what he calls strong and weak concepts of the Divine: A strong concept holds that the Divine, or transcendence, is ultimate in all three dimensions of transcendence; a weak concept is just that the Divine is the ultimate value and the ultimate source of good for us (Schellenberg 2013:96). His preference is to think of transcendence in the mode of 'thin'/'strong' - strong, because of the triple ultimacy that faith seeks, and thin because humans with their limited mind need to be cautious about imagining that they are capable of detailed knowledge of the nature of the Divine (Schellenberg 2013:97).

In summary, he argues that 'the fundamental idea of evolutionary religion would be an idea of something deepest in reality (metaphysically ultimate) that is also unsurpassably great (axiologically ultimate) and the source of our deepest good (soteriologically ultimate)'; he calls this religious perspective ultimism (Schellenberg 2013:99). Echoing the traditional theological belief that the deity is both transcendent and immanent, 


\section{Martin Prozesky}

Schellenberg comments that ultimism posits a reality that is "not so distant as to be incapable of touching us' but not too close to us either (Schellenberg 2013:100).

This is followed by Schellenberg's account of faith in this evolutionary religious perspective (Schellenberg 2013:100ff). His account calls to mind and accords with the seminal work of Wilfred Cantwell Smith (1979) on faith and belief - work which appears not be known to Schellenberg. Smith's contribution to a deeper understanding of faith is his distinction between faith and belief, with the latter being understood to mean the acceptance of certain propositions as true, for example that angels exist (Smith 1979:9). Smith shows that this is not what belief originally meant at all, for the word derives from Latin and Germanic words that can be translated as 'to set your heart on something' (Smith 1979:76, 106ff). Far from merely giving your assent to propositions like those in the creeds of the church and its doctrines, faith is 'to be faithful, to care, to trust, to cherish, to be loyal, to commit oneself' to a transcendent reality (Smith 1979:117). For Schellenberg, faith would not involve belief, whose involuntary nature is not appropriate to a faith that understands its own intellectual limitations and is open to deeper and better spiritual insight. Instead it would involve imagination.

Turning then to the life of faith that goes with ultimism, Schellenberg notes that if ultimism is true, then 'the core of reality is on the side of the good, and may indeed in some sense be the good' (Schellenberg 2013:107). The significance of this contention for an evolutionary religious ethic is clear and is said to involve three directions: Downward, inward, and outward.

The first of these - the downward direction - means seeking the best understanding from any and all sources and experiences of transcendence, as well as being free of the way an existing religious belief often stands in the way of such an exciting quest for richer truth (Schellenberg 2013:107ff). The inward direction of faith takes us into ourselves and enables us to know ourselves as capable of reordering ourselves to align with reality at its deepest, beyond anything that science, for all its glory, can reveal (Schellenberg 2013:109ff). This reordering reveals that acquisitiveness and anxiety are unfounded and can be overcome, giving way to self-control, contentment, and serenity. The third direction of faith is a matter of turning outward. It engages us with others and the world in ways that align with ultimism, and it both justifies and encourages greater commitment to seek and do good even when risk is involved (Schellenberg 2013:110ff). Schellenberg hints here at his 
earlier contention that ultimacy is also about supreme value, and with it, supreme relevance to us, in its capacity for us to be aligned to the unsurpassably valuable, but he does not say what this could be.

Next is a discussion of religious community (Schellenberg 2013:112). Schellenberg argues that ultimism's evolutionary faith is a 'movement away from egoistic, self-concern' and endorses the valuable life of religious community with others (Schellenberg 2013:113). The 'others' are not limited to members of particular religious orientation, for the intellectual quality of this evolutionary and modest mentality, with its 'thin' view of transcendence, seeks inclusion and openness - not closure - which makes for an acceptance of religious pluralism. It also permits one to retain aspects of what religion so far has been, as part of a journey into a new spiritual future, moving 'toward all that only the future may reveal of what is most beautiful, good, and true' (Schellenberg 2013:115).

Having discussed the parameters of evolutionary faith, Schellenberg proceeds in chapter 7 to consider and counter various objections to it (Schellenberg 2013:116-136), e.g. issues of evil where, among other things, he notes that 'personality, at least as we know it, may not at all be part of the Ultimate' (Schellenberg 2013:120); the contention that an afterlife is impossible; and the accusations of wishful thinking, of merely being a type of new age religion, and of having no chance of ever catching on. In the final chapter, Schellenberg (2013:137-156) depicts evolutionary religion as a religion for pioneers - for those who first explore new spaces.

The very nature of this kind of faith is said to make it ideal for those with a pioneering disposition, because it is radically open to a future that could be immensely long, also because of its open-mindedness and its acceptance that, in the vast total possible span of human existence, humankind is now at a very early stage of development, indeed in key respects in an incomplete, even mistaken stage, like believing that they already know the last word about ultimate reality. In this pioneering spirit, Schellenberg reviews and transforms the traditional arguments for the existence of God, rejected as failures by thinkers like Anselm, Leibniz, Paley, and James, by using them in reinterpreted ways to enhance evolutionary faith in a triply transcendent Divine and showing that it is an ideal home for such richness of understanding, values, and spiritual concerns.

Anselm's concept of a reality of which a greater one cannot be conceived, is made into an encouragement to enlarge our mind and vision - 


\section{Martin Prozesky}

open to really big ideas (Schellenberg 2013:141ff). Leibniz can foster, in those willing to adopt the imaginative faith that Schellenberg explores, a commitment to enhanced intellectual understanding (Schellenberg 2013:144ff), and Paley's teleological argument can become an encouragement to cherish and protect the beauty of the universe and even discerns that beauty runs 'deep in reality too' (Schellenberg 2013:147ff). Schellenberg states, 'In the practice of evolutionary religion, experiences of beauty will be regarded as possible intimations of a transcendent reality' (Schellenberg 2013:148).

In what can be judged the most important words in the book, he adds that 'the dream of religion - if indeed the ultimate dream - can be of nothing less than a good embracing all that exists' (Schellenberg 2013:149).

The last of the thinkers with whom Schellenberg engages in this final chapter, is James (Schellenberg 2013:150-156). His well-known pragmatism is developed into 'a powerful, teeth-gritting determination to imagine and live by what ought to be the case', as long as this is not ruled out by evidence (Schellenberg 2013:154). Continuing in this vein, he adds that

ultimism, which tells us that the ultimate reality is ultimately valuable and the source of an ultimate good in which we can participate, leaves open the door to some sort of redemption for all those lives that have been and continually are being crushed, often before they have had a chance to be fully formed; and for that reason alone ultimism ought to be true (Schellenberg 2013:155).

By living out such a faith we can help to show that it is indeed true. That a rich ethic is inherent in such a faith is well expressed by the words that end the chapter, which declare that evolutionary religion 'looks not for consolation and an escape from the world as it is but a pioneering hope and determination that may be spent on behalf of others and a world still being born' (Schellenberg 2013:156).

In a short Epilogue (Schellenberg 2013:157f), Schellenberg ingeniously uses the dialectical notion attributed to Hegel, that things develop through the interaction of a reality (the 'thesis') which is judged by its critics to be flawed, or worse (the 'antithesis'), giving rise to a new reality (the 'synthesis'). Here might be a doorway to concluding that traditional religion can be seen as the thesis, which Enlightenment rationality dismantles as the antithesis, signaling not the end of religion as Lewis-Williams and others like 
him contend, but a rebirth in the form of evolutionary, imaginative faith - the Hegelian synthesis - drawing on the best in both the thesis and the antithesis, to 'stimulate and guide the next stages of human evolution' (Schellenberg 2013:158).

\section{Critical discussion}

Three main issues requiring critical appraisal arise from the foregoing accounts: First, the adequacy, respectively of Lewis-Williams' narrow definition of religion as belief in supernatural beings and forces, and Schellenberg's broader view that religion is best seen in soteriological terms as evolving faith in that which is found to provide the most valuable of benefits; the second issue is the adequacy of their very different views about whether religion has a future; and third, the light they shed on the two methodological strategies of interpreting and explaining religion - an issue on which David Chidester has shed valuable light.

On the first critical issue, the question to Lewis-Williams (and others who share his view, like Grayling), is whether the definition of religion as belief in supernatural beings and realms is justified. The term 'religion' is commonly held to refer to a cluster of socio-personal phenomena which, despite very great differences of detail, exhibit what has been called a family resemblance. This resemblance consists of two related, basic dimensions which we could term as their ontological and their personal or existential dimensions.

The former refers to the fact that believers orientate their life to what they regard as transcendent, as surpassing ordinary existence in some way, such as one or more deities or an encompassing tendency in the cosmos like the Tao, which can be experienced but is not amendable to scientific investigation. The personal or existential dimension refers to the way believers take this ontological dimension with utmost seriousness, holding that it is what concerns them most like finding an assurance of a desirable afterlife. In expressing this belief, they develop and practice appropriate rituals, form communities, tell symbolic stories, and create supportive institutions. These can be observed in Buddhism, which does not involve a belief in supernatural 


\section{Martin Prozesky}

beings - as in the theistic faiths, which obviously do, and which concern LewisWilliams mostly.

My problem with his definition of religion is that it arbitrarily selects as definitive one example - belief in supernatural beings - which I am calling the ontological dimension of the movements commonly seen as religion, thereby leaving out of consideration as religious the remaining features that reveal the family resemblance noted above. His account would gain in acceptability, had it been directed just at belief in supernatural beings and forces, about which he has important things to say as we have seen, and not at religion in general. Doing so, would not exclude other manifestations from the category of religion and does not, arguably, exclude from the study of religion the rich range of manifestations about which David Chidester has written, ranging from what he calls savage systems to authentic fakes and wild religion (Chidester 1996; 2005; 2012).

For the same reason I regard Schellenberg's much more inclusive view of religion to be methodologically sounder than that of Lewis-Williams. However, is Schellenberg justified when he singles out the soteriological function of religion as its key feature? My own, very wide-ranging study of religious data led me to the same view (Prozesky 1984:18-50) - a conclusion also reached by Hick in his magnum opus, An interpretation of religion (Hick 1989:21-55). If this conclusion is incorrect, based as it is for both Hick and myself on evidence from a wide range of religious and scholarly sources, I have yet to see it convincingly reproduced.

My second critical issue concerns the future of religion. LewisWilliams holds that there is no good evidence to support a belief in a supernatural order of beings so that it will prove unsustainable. Thus defined, religion therefore has no future. Let me grant, for argument's sake, that he is correct about the non-existence of supernatural beings of any kind. That does not entail that the belief in them will wither away, definitely not in the short to middle term of the next few generations and longer, because it is simply incorrect that supernaturalist religious belief is nourished by and dependent mainly on intellectual concern for scientifically verifiable evidence. On the contrary, feelings and emotions play a decisive part in winning and retaining religious allegiance, as classical studies of religious experience from the pioneering work of Friedrich Schleiermacher onward show (Schleiermacher 1799; James 1902; Starbuck 1914; Hardy 1979; Battson \& Ventiss 1982). 
It seems impossible to prove the non-existence of spiritual beings, and as long as their existence, power, and favor are believed in, especially a belief in one such supreme, beneficent being, the feelings of security, protection, and comfort this generates in believers make it overwhelmingly likely that such belief will continue for a very long time. Above all, it is hard to exaggerate the emotional value to some believers of the sense that their faith saves them from a truly horrific fate in an afterlife.

Church-going is nowadays evidently far less prevalent in secular, Western Europe than it was several generations ago, but it has not gone and is reportedly growing significantly in other parts of the world like formerly communist countries where huge pressures against it were brought about by the state, for well over half a century in the case of the former Soviet Union (Micklethwaite \& Wooldridge 2009). It is also evident in Western Europe that religious observance in other theistic faiths like Islam, Judaism, Sikhism, and parts of Hinduism, is not waning.

Ironically, a more inclusive concept of religion than just belief in supernatural beings actually assists Lewis-Williams' critique of that belief, because it obliges the supernaturalist to explain why non-theists of such outstanding intellectual, spiritual, and ethical standing as the Dalai Lama, reject it, if beings like these actually exist - above all if they are everywhere.

Schellenberg's view that religion will continue to be part of human existence for as long as the species exists is in my judgment much more plausible than predictions of its demise, for it is supported by at least three considerations: The first is his foregrounding of what he calls the soteriological element, with its powerful emotional attraction, and I produced indications above from the nature of religious experience as to why this makes the endurances of religion a virtual certainty. Next, Schellenberg's open-ended, metaphysically minimalist view of the object of religious concern allows for very great changes over time in the way that object of faith is conceived, especially if human brain-power evolves to ever greater cognitive capabilities. As long as such changes retain the all-important soteriological function, and as long as its human subjects remain vulnerable and drawn by the appeal of that function, religion will endure, albeit in forms we cannot now conceive. The third factor in support of Schellenberg about the lengthy future of religion is evolution itself and the scientific evidence that our planet can support life for an immensely long time to come, barring a planetary catastrophe like the impact of a truly massive comet which will destroy most forms of life including 
our own. This being the case, the persistence of religion as Schellenberg sees it is indeed highly likely and even certain.

My final critical issue is about interpretation and explanation - an issue that has greatly interested me since researching and writing my first book (Prozesky 1984:68-98). Lewis-Williams regards his treatment of religion as explanatory in nature, in that he holds that he has identified its causes from the way the brain works (Lewis-Williams 2010:9, 115-138). It is this strong sense of the term 'explanation' as causal explanation that he has in mind, not the weaker sense where it means no more than clarifying something. Schellenberg makes no such claim, being concerned to indicate what religion is, and not why it exists. This brings us to an important insight made by Chidester early in his career in South Africa. I recall him pointing out that while interpretations of religion involve no more than being interesting, in the sense that they illuminate and deepen understanding in significant ways, explanation involves the daunting requirement of being true, or at least significantly more plausible than other explanations (cf. Chidester 1985:80, 86).

Schellenberg's interpretation of religion is indeed immensely illuminating and interesting, compared to that of Lewis-Williams, which is a much narrower view of religion. What must be asked, in the light of Chidester's important observation, is whether Lewis-William's purported explanation of supernaturalism is true, or at least more plausible than other explanations. The issue can be stated as follows: What is better supported by all the evidence, as the more likely cause of widespread and very long-lasting belief in one or more supernatural beings, is the question about their real, objective existence, which they make evident to people in various revelatory ways, or is it just the way the human brain projects the personal onto the purely natural forces that affect us, making us see them as gods and as other spiritual beings, and ultimately, for monotheists, as one supreme being?

Judging the plausibility of Lewis-Williams' explanation is a complex matter and beyond the scope of this article. What can be done is to propose a number of considerations, both in support of and against his theory. In favor of it is human brain science (Ashbrook \& Albright 1997; Van der Walt 2010:2339). There is no doubt that the brain does indeed enable us to project the familiar onto the strange and mysterious as Lewis-Williams argues. Then there is the support that supernaturalists themselves unintentionally give to his explanation. While they would strongly contest it for their own belief, their rejection of the same kind of belief in other religions means that they regard 
them as mere human creations. How many theists, for example, would also believe that Zeus and his fellow deities in fact exist on Mount Olympus? Philosophers of religion have also long cited pain, suffering, and other evils as counting against the existence of the beneficent deity of the most widely followed theistic faiths.

Against Lewis-Williams and all the other attempts to refute supernaturalism on the basis of projective human brain functioning, is the response that theists themselves can easily give, to which I alluded earlier in this article. They can quite consistently reply that our brain was designed by the Creator in whom they believe to enable humanity to come to an awareness of their divine source. I therefore suspect that Chidester's warning about trying to explain religion causally results, for Lewis-William's attempt to do so, at best in a split vote: Skeptics will agree with his explanation, while believers will not. My own verdict is that for all its immense erudition and valuable warnings about unethical religious practices, his attempt at a causal explanation of belief in supernatural beings on the basis of human brain science fails.

\section{References}

Ashbrook, J. \& C.R. Albright 1997. The humanizing brain: Where religion and neuroscience meet. Cleveland: The Pilgrim Press.

Battson, C.D. \& W.L. Ventiss 1982. The religious experience. New York: Oxford University Press.

Chidester, D. 1985. Theory and theology in the study of religion. Religion in Southern Africa 6, 2: 75-94.

Chidester, D. 1996. Savage systems: Colonialism and comparative religion in Southern Africa. Charlottesville: University Press of Virginia.

Chidester, D. 2005. Authentic fakes: Religion and American popular culture. Berkeley: University of California Press.

Chidester, D. 2012. Wild religion: Tracking the sacred in South Africa. Berkeley: University of California Press.

Dawkins, R. 2006. The God delusion. London: Bantam Press.

Grayling, A.C. 2013. The God argument: The case against religion and for humanism. New York: Bloomsbury. 
Hardy, A. 1979. The spiritual nature of man: A study of contemporary religious experience. Oxford: Clarendon Press.

Harris, S. 2006. Letter to a Christian nation. New York: Knopf.

Hick, J. 1989. The interpretation of religion: Human responses to the transcendent. London: Macmillan.

Hutchinson, J.A. 1981. Paths of faith. $3^{\text {rd }}$ ed. New York: McGraw-Hill Education.

James, W. 1902. The varieties of religious experience: A study in human nature. London: Longmans, Green \& Co.

Lewis-Williams, D. 2010. The cognitive origin and evolution of religion. London: Thames \& Hudson.

Micklethwaite, J. \& A. Wooldridge 2009. God is back: How the global rise of faiths is changing the world. London: Allen Lane.

Prozesky, M. 1984. Religion and ultimate well-being: An explanatory theory. London: Macmillan.

Schellenberg, J.L. 2005. Prolegomena to a philosophy of religion. Ithaca: Cornell University Press.

Schellenberg, J.L. 2007. The will to doubt: A justification of religious skepticism. Ithaca: Cornell University Press.

Schellenberg, J.L. 2009. The will to imagine: A justification of skeptical religion. Ithaca: Cornell University Press.

Schellenberg, J.L. 2013. Evolutionary religion. Oxford: Oxford University Press.

Schleiermacher, F.D.E. 1799. On religion: Addresses in response to its cultured despisers. Tice, T.N. (trans.). Richmond: John Knox Press.

Smart, N. \& R.D. Hecht (eds.) 1982. Sacred texts of the world: A universal anthology. London: Macmillan Reference Books.

Smith, W.C. 1979. Faith and belief. Princeton: Princeton University Press.

Starbuck, E.D. 1914. The psychology of religion: An empirical study of the growth of religious consciousness. $4^{\text {th }}$ ed. London: The Walter Scott Publishing Company.

Van der Walt, E. 2010. The limbic system and the 'religious brain'. In Du Toit, C.W. (ed.): Homo transcendentalis? Transcendence in science and religion: Interdisciplinary perspectives. Pretoria: UNISA Press. 
Will Religion Survive?

Martin Prozesky

School of Religion, Philosophy and Classics University of KwaZulu-Natal marproz@mweb.co.za 